\title{
Status of Alternaria Leaf Spot of Bottle gourd [Lagenaria siceraria (Molina) Standl.] in Temperate Kashmir
}

\author{
Masrat Ul Nisar, Nazir Ahmad Bhat, Roaf Ahmad Rather*, \\ Farheen Chasti and Tanveer Ahmad Wani
}

Department of Plant Pathology FoA, SKUAST-K, Wadura Sopore, J\&K-193201, India

*Corresponding author

\section{A B S T R A C T}

\begin{tabular}{|c|}
\hline Keywords \\
\hline $\begin{array}{l}\text { Bottle gourd [Lagenaria } \\
\text { siceraria (Molina) } \\
\text { Standl.], Alternaria Leaf } \\
\text { Spot, Temperate }\end{array}$ \\
\hline Article Info \\
\hline $\begin{array}{l}\text { Accepted: } \\
\text { 20 September } 2018 \\
\text { Available Online: } \\
10 \text { October } 2018\end{array}$ \\
\hline
\end{tabular}

Alternaria leaf spot of bottle gourd is one of the most important diseases of bottle gourd [Lagenaria siceraria (Molina) Standl.]. The present study was, therefore, carried out to know the status of the disease in Kashmir valley. The disease was found prevalent in all the vegetable growing areas of Kashmir valley surveyed. The overall mean disease incidence and intensity ranged from 9.25 to 12.4 per cent and 2.9 to 4.36 per cent, respectively, during the pre-flowering stage of the crop. However, during fruit development stage, the increased incidence and intensity was recorded which ranged from 22.35 to 23.76 and 6.1 to 6.6 per cent, respectively. The maximum disease incidence of 12.4 and 23.76 per cent and intensity of 4.36 and 6.60 per cent, respectively during first and second stage of survey was observed in district Budgam and minimum disease incidence of 9.25 and 22.35 per cent and intensity of 2.9 and 6.1 per cent, respectively, was in district Anantnag. Further, during second stage of survey fruit infection and unmarketable culls were also recorded. The maximum fruit infection and unmarketable culls were found in district Budgam7.48 and $28.44 \%$, respectively.

\section{Introduction}

Vegetables are highly beneficial for maintenance of human health, maintaining alkaline reserve of body and prevention of diseases owing to presence of sufficient quantities of carbohydrates, minerals and vitamins in them (Robinson, 1990). India is the second largest producer of vegetables in the world next only to China with an estimated production of about 162187 thousand metric tonnes from an area of 9205 thousand hectares at productivity of 17.62 metric tonnes per hectare, where as in Jammu and Kashmir, the area under vegetables is 63.1 thousand hectares and production is 1395.5 thousand metric tonnes (Anonymous, 2016). Bottle gourd (Lagenaria siceraria) is the most popular vegetables of the family Cucurbitaceae, which forms an excellent diet being rich in vitamins iron and minerals (Milind and Kaur, 2011). The edible portion of lauki (Bottle gourd) is a fair source of ascorbic acid, beta carotene and a good source of vitamin B complex, pectin and dietary soluble fibers (Modgil et al., 2004). Fruits contain 96.3 per cent moisture; vitamin C (11 $\mathrm{mg}$ ), Thiamine (0.044 mg), Riboflavin (0.023 
mg) Niacin $(0.33 \mathrm{mg})$, mineral matters $(0.05 \%)$, carbohydrates $(2.9 \%)$, fats $(0.5 \%)$ and protein $(0.02 \%)$ and its different parts possess large number of medicinal properties (Desai and Musmade, 1998). It has originated in Africa (Singh, 1990) and from there by floating on the sea, it travelled to India, where it has evolved into numerous local varieties and has spread to China, Indonesia and far to New Zealand. In India the crop is grown commercially in most of the states like U.P, Bihar, West Bengal, Assam, Punjab and Gujarat.

The cultivation of bottle gourd is affected by a number of diseases caused by fungi, bacteria and viruses, which cause huge losses in fruit yield. Among fungal diseases, Alternaria leaf blight and leaf spot caused by Alternaria spp. are among the most important diseases of bottle gourd (Maheshwari et al., 2017). The disease affects foliage as well fruit (Seebold, 2010). It has been reported that $100 \%$ yield loss occurred in cucurbits infected by Alternaria cucumerina (Watt, 2013) and 80$88 \%$ due to Alternaria alternata (Bhargava and Singh, 1985).

\section{Materials and Methods}

\section{Survey}

Survey for prevalence and severity of alternaria leaf spot of bottle gourd was conducted in three vegetable growing districts of Kashmir valley viz., Anantnag, Baramulla and Budgam. Major vegetable growing belts were identified from each of the districts and three locations were randomly selected from each of these belts.

Bottle gourd plants were ear marked in the vegetable fields at three sites of each location, which were visited twice and observations recorded on randomly selected vines for presence of the disease.

\section{Assessment of disease incidence}

In each of the selected field (site), five vines (hills) of plants were selected randomly for recording observations on leaves, four radial branches each, which were keenly observed for alternaria leaf spot symptoms. During the first stage of survey, conducted just before flowering stage, total number of diseased and healthy leaves on the randomly selected vines was recorded but during second survey, conducted after fruit formation, five radial vines were randomly selected from each hill to record the observations on their leaves. Disease incidence was calculated using the formula:

Disease incidence $(\%)=\frac{\mathrm{n}}{\mathrm{N}} \times \frac{----}{\mathrm{N}} \times 100$

Where, $\mathrm{n}$ is the number of leaves showing leaf spot symptoms and $\mathrm{N}$ is the total number of leaves observed in each field.

Average of three fields (sites) represented the average disease incidence of respective localities.

\section{Disease intensity}

The leaves observed for disease were graded according to $0-5$ scale given by Maheswari and Choudhary (2015):

0: No symptoms

1: $0.1-0.9 \%$ leaf area affected

2: $1-10 \%$ leaf area affected

3: $10.1-25 \%$ leaf area affected

4: $25.1-50 \%$ leaf area affected

5: $50.1-100 \%$ leaf area affected.

The sum of numerical rating according to the given scale was computed and used to calculate disease intensity by the formula given by Mabbett and Phelps (1984): 
Disease intensity $(\%)=\frac{\sum \mathrm{nv}}{\mathrm{N} \times \mathrm{G}} \times 100$

Where,

$\sum$ : Summation

v: Disease score

$\mathrm{n}$ : Number of leaves showing a particular score.

$\mathrm{N}$ : Number of leaves examined.

G: Maximum Score.

\section{Disease incidence on fruits}

Disease incidence on fruits was recorded during second stage of survey and was assessed on the basis of number of fruits available on plants at the time of survey. Total number of fruits and fruits showing characteristic disease symptoms was counted. Out of the infected fruits, the fruits which were rotten or mummified that could not be accepted by the consumer were counted and classified as unmarketable culls. The per cent infected fruits and per cent unmarketable culls were also calculated.

\section{Results and Discussion}

\section{Survey for recording disease status}

With a view to find out the status of leaf spot of bottle gourd in Kashmir valley, survey of important cucurbit growing belts of district Anantnag, Baramulla and Budgam was conducted during kharif 2016. Incidence and intensity of leaf spot of bottle gourd was recorded in both the stages whereas, per cent fruit infection and per cent unmarketable culls were recorded in second stage of survey only. The data recorded is presented in Tables 1-6.

\section{Disease incidence}

The data (Table 1) reveals that leaf spot of bottle gourd was prevalent in all locations surveyed with varying degrees of incidence, which was minimum in first but maximum in second stage of survey. Disease incidence in the first stage of survey ranged between 7.1 to 14.9 per cent and in second stage of survey between 17.46 to 26.13 per cent, respectively.

Highest disease incidence of 14.9 per cent at first stage of survey was recorded at Chakla, Baramulla, followed by Wagoora, Budgam (13.6\%), Kaisarmulla, Budgam (13.5\%), Stadium colony, Baramulla (13.4\%), Kremshore, Budgam (13\%), Dawlatpora, Budgam (12.8\%) and Haji-Dantar, Anantnag (11.33\%), respectively. During the second stage of survey, the disease incidence at these locations was 22.7, 23.5, 24.8, 22.1, 24, 23.9 and $23.6 \%$, respectively. However, highest disease incidence during second stage of survey was recorded at Lalan, Anantnag (26.13\%) followed by UttarasooNajigund, Anantnag (25.50\%), Kaisarmulla, Budgam (24.8\%), Nowbugh, Budgam (24.7\%), Arampora, Baramulla (24.6\%), Nehalpora, Baramulla (24.4\%), Wusan, Baramulla (24.4\%) and Kremshore, Budgam (24\%), respectively. In district Anantnag highest disease $(11.33 \%)$ was recorded at Haji-Dantar and lowest $(7.60 \%)$ at Sagam during first stage of survey. During second stage of survey, highest and lowest disease incidenceof 26.13 and $17.46 \%$ in district Anantnag was recorded at Lalan and HilarArhama respectively. In district Baramulla highest disease (14.9\%) was recorded at Chakla and lowest $(7.1 \%)$ at Wadura during first stage of survey. During second stage of survey, highest and lowest disease incidence of 24.6 and $20.6 \%$ in district Baramulla was recorded at Armpora and Johama, respectively. In district Budgam highest disease $(13.6 \%)$ was recorded at Wagoora and lowest (10.33\%) at Bugam 
during first stage of survey. During second stage of survey, highest and lowest disease incidence of 24.8 and $23 \%$ in district Budgam was recorded at Kaisarmulla and Bugam respectively. Perusal of data reveals that amongst the districts surveyed, highest mean disease incidence of 12.4 per cent was recorded in case of district Budgam followed by Baramulla (10.62\%) and Anantnag $(9.25 \%)$.

\section{Disease intensity}

The data presented in Table 2 reveals that Alternaria leaf spot was prevalent on bottle gourd in all locations surveyed with varying degrees of intensity, which was minimum in first but maximum in second stage of survey. Disease intensity in the first stage of survey ranged between 2.11 to 5.2 per cent and in second stage of survey between 4.9 and 7.51 per cent, respectively.

Highest disease intensity of 5.2 per cent at first stage of survey was recorded at Chakla, Baramulla, followed by Kremshore, Budgam (5.10\%), Wagoora, Budgam (5.06\%), Kaisarmulla, Budgam (5\%), Stadium colony, Baramulla (4.8\%), Dawlatpora, Budgam (4.39\%), Johama, Baramulla (3.9\%) and Nehalpora, Baramulla (3.7\%). During second stage of survey, the disease intensity at these location was $6.2,5.3,7.51,7.5,5.7,6.8,6.0$ and $7.4 \%$ respectively. However, highest disease intensity of 7.51 per cent was recorded during second stage of survey at Wagoora, Budgam followed by Kaisarmulla, Budgam (7.5\%), Nowpora, Baramulla (7.5\%), Nehalpora, Baramulla (7.4\%), Bugam, Budgam (7.4\%), Larkipora, Anantnag (7.31\%) and Arampora, Baramulla (7.3\%). In district Anantnag highest disease intensity (3.6\%) was recorded at HilarArhama and lowest (2.4\%) at Shangrin during first stage of survey. During second stage of survey highest $(7.3 \%)$ and lowest $(4.9 \%)$ disease intensity in district
Anantnag was recorded at Larkipora and HilarArhama, respectively. In district Baramulahighest disease intensity $(5.2 \%)$ was recorded at Chakla and lowest $(2.11 \%)$ at Wadura during first stage of survey. During second stage of survey highest and lowest disease intensity (7.5 and $5.5 \%)$ in district Baramulla was recorded at Wusan and Arampora, respectively. In district Budgam highest disease intensity $(5.10 \%)$ was recorded at Kremshore and lowest $(3.5 \%)$ at Kuthipora during first stage of survey. During second stage of survey highest and lowest disease intensity of $7.51 \%$ and $5.3 \%$ in district Budgam was recorded at Wagoora and Kremshore, respectively. Amongst the districts surveyed highest mean disease intensity of 4.36 per cent was also recorded in case of district Budgam followed by Baramulla (3.39\%) and Anantnag (2.9\%).

\section{Fruit infection and unmarketable culls}

Data presented in Table 3 reveals that some of the fruits present on plants at second stage of survey in all the fields surveyed exhibited symptoms of the disease, Out of which, good number of fruits were infected to the extent that these could not be accepted in the market and as such were graded as unmarketable culls. Infected fruits ranged from $5.15 \%$ recorded at Haji-Dantar (District Anantnag) to 9.21\% recorded at Kremshore in district Budgam. Out of these, unmarketable culled fruits ranged between 23 to $31 \%$ recorded at the Mehmoodabad in district Anantnag and at Kaisarmulla in district Budgam respectively. The data further reveals that highest fruit infection was recorded in Kremshora, Budgam $(9.21 \%)$ followed by Wagoora, Budgam (8.7\%), Kuthipora, Budgam (8.59\%), Arampora Baramulla (8.49\%), Larnoo, Anantnag (8.2\%), Bugam, Budgam (7.72\%), Wager, Budgam (7.54\%), Larkipora, Anantnag (7.50\%) and Kaisarmulla, Budgam $(7.45 \%)$, respectively. 
Table.1 Incidence of alternaria leaf spot of bottle gourd on leaves at Various locations of Kashmir

\begin{tabular}{|c|c|c|c|c|c|c|c|c|}
\hline \multirow[t]{2}{*}{ District } & \multirow[t]{2}{*}{ Belt } & \multirow[t]{2}{*}{ Locations } & \multirow[t]{2}{*}{ Stage 1} & \multicolumn{2}{|c|}{ C.I (95\%) } & \multirow[t]{2}{*}{ Stage 2} & \multicolumn{2}{|c|}{ C.I $(95 \%)$} \\
\hline & & & & $\begin{array}{c}\text { Lower } \\
\text { limit }\end{array}$ & $\begin{array}{l}\text { Upper } \\
\text { limit }\end{array}$ & & $\begin{array}{c}\text { Lower } \\
\text { limit }\end{array}$ & $\begin{array}{c}\text { Upper } \\
\text { limit }\end{array}$ \\
\hline \multirow{13}{*}{ Anantnag } & \multirow[t]{4}{*}{ Achabal } & Haji Danter & 11.33 & & & 23.59 & & \\
\hline & & UttarasooNajigund & 8.04 & & & 25.50 & & \\
\hline & & Lalan & 8.56 & & & 26.13 & & \\
\hline & & Sub mean & 9.31 & 7.32 & 11.30 & 25.07 & 23.58 & 26.56 \\
\hline & \multirow[t]{4}{*}{ Breng } & Sagam & 10.00 & & & 21.23 & & \\
\hline & & Larnoo & 10.66 & & & 21.03 & & \\
\hline & & HilarArhama & 9.90 & & & 17.46 & & \\
\hline & & Sub mean & 10.18 & 9.72 & 10.64 & 20.00 & 17.60 & 22.40 \\
\hline & \multirow[t]{5}{*}{ Dooru } & Larkipora & 9.30 & & & 23.10 & & \\
\hline & & Shangrin & 7.60 & & & 22.30 & & \\
\hline & & Mehmooabad & 7.90 & & & 20.60 & & \\
\hline & & Sub mean & 8.26 & 7.24 & 9.27 & 22.00 & 20.56 & 23.43 \\
\hline & & Mean & 9.25 & 8.16 & 10.33 & 22.35 & 19.46 & 25.23 \\
\hline \multirow[t]{13}{*}{ Baramulla } & \multirow[t]{4}{*}{ Sopore } & Arampora & 8.30 & & & 21.80 & & \\
\hline & & Chinkipora & 8.60 & & & 24.10 & & \\
\hline & & Wadura & 7.10 & & & 23.80 & & \\
\hline & & Sub mean & 8.00 & 7.10 & 8.89 & 23.23 & 21.81 & 24.64 \\
\hline & \multirow[t]{4}{*}{ Pattan } & Palhalan & 9.10 & & & 24.60 & & \\
\hline & & Wusan & 11.60 & & & 24.20 & & \\
\hline & & Nehalpora & 10.80 & & & 24.40 & & \\
\hline & & Sub mean & 10.50 & 9.06 & 11.93 & 24.40 & 24.17 & 24.63 \\
\hline & \multirow{5}{*}{$\begin{array}{l}\text { Baramulla } \\
\text { (Tehsil) }\end{array}$} & Stadium colony & 13.40 & & & 22.10 & & \\
\hline & & Johama & 11.80 & & & 20.60 & & \\
\hline & & Chakla & 14.90 & & & 22.70 & & \\
\hline & & Sub mean & 13.36 & 11.61 & 15.11 & 21.80 & 20.58 & 23.02 \\
\hline & & Mean & 10.62 & 7.57 & 13.67 & 23.14 & 21.67 & 24.67 \\
\hline \multirow[t]{14}{*}{ Budgam } & \multirow[t]{4}{*}{ Khansahib } & Kremshore & 13.00 & & & 24.00 & & \\
\hline & & Khansahib & 11.00 & & & 23.00 & & \\
\hline & & Wager & 12.40 & & & 24.00 & & \\
\hline & & Sub mean & 12.10 & 10.94 & 13.25 & 23.66 & 23.01 & 24.30 \\
\hline & \multirow[t]{4}{*}{ Chadoora } & Bugam & 10.33 & & & 23.00 & & \\
\hline & & Kaisarmulla & 13.50 & & & 24.80 & & \\
\hline & & Nowbugh & 13.07 & & & 24.70 & & \\
\hline & & Sub mean & 12.30 & 10.36 & 14.23 & 24.16 & 23.05 & 25.30 \\
\hline & \multirow[t]{5}{*}{ B.K Pora } & Kuthipora & 12.00 & & & 23.00 & & \\
\hline & & Wagoora & 13.60 & & & 23.50 & & \\
\hline & & Dawlatpore & 12.80 & & & 23.90 & & \\
\hline & & Sub mean & 12.80 & 11.90 & 14.23 & 23.46 & 22.95 & 23.96 \\
\hline & & Mean & 12.40 & 11.99 & 12.80 & 23.76 & 23.35 & 24.16 \\
\hline & \multicolumn{2}{|c|}{ Overall Mean } & 10.75 & 8.96 & 12.54 & 23.08 & 22.29 & 23.87 \\
\hline
\end{tabular}


Table.2 Intensity of alternaria leaf spot of bottle gourd on leaves at various location of Kashmir

\begin{tabular}{|c|c|c|c|c|c|c|c|c|}
\hline \multirow[t]{2}{*}{ District } & \multirow[t]{2}{*}{ Belt } & \multirow[t]{2}{*}{ Locations } & \multirow[t]{2}{*}{ Stage 1} & \multicolumn{2}{|c|}{ C.I $(95 \%)$} & \multirow[t]{2}{*}{ Stage 2} & \multicolumn{2}{|c|}{ C.I $(95 \%)$} \\
\hline & & & & $\begin{array}{l}\text { Lower } \\
\text { Limit }\end{array}$ & $\begin{array}{l}\text { Upper } \\
\text { Limit }\end{array}$ & & $\begin{array}{l}\text { Lower } \\
\text { Limit }\end{array}$ & $\begin{array}{l}\text { Upper } \\
\text { Limit }\end{array}$ \\
\hline \multirow[t]{13}{*}{ Anantnag } & \multirow[t]{4}{*}{ Achabal } & Haji Danter & 3.06 & & & 6.70 & & \\
\hline & & $\begin{array}{l}\text { UttarasooNajigun } \\
\text { d }\end{array}$ & 2.26 & & & 7.10 & & \\
\hline & & Lalan & 2.92 & & & 6.00 & & \\
\hline & & Sub mean & 2.74 & 2.27 & 3.21 & 6.60 & 5.98 & 7.22 \\
\hline & \multirow[t]{4}{*}{ Breng } & Sagam & 3.40 & & & 5.00 & & \\
\hline & & Larnoo & 3.19 & & & 5.70 & & \\
\hline & & HilarArhama & 3.60 & & & 4.90 & & \\
\hline & & Sub mean & 3.36 & 3.13 & 3.58 & 5.20 & 4.71 & 5.68 \\
\hline & \multirow[t]{5}{*}{ Dooru } & Larkipora & 3.00 & & & 7.31 & & \\
\hline & & Shangrin & 2.40 & & & 6.70 & & \\
\hline & & Mehmooabad & 2.50 & & & 5.80 & & \\
\hline & & Sub mean & 2.60 & 2.23 & 2.96 & 6.60 & 5.74 & 7.46 \\
\hline & & Mean & 2.90 & 2.45 & 3.35 & 6.10 & 5.20 & 7.00 \\
\hline \multirow[t]{13}{*}{ Baramulla } & \multirow[t]{4}{*}{ Sopore } & Arampora & 2.60 & & & 5.50 & & \\
\hline & & Chinkipora & 2.40 & & & 6.90 & & \\
\hline & & Wadura & 2.11 & & & 6.50 & & \\
\hline & & Sub mean & 2.37 & 2.10 & 2.64 & 6.30 & 5.49 & 7.11 \\
\hline & \multirow[t]{4}{*}{ Pattan } & Palhalan & 2.80 & & & 7.30 & & \\
\hline & & Wusan & 3.30 & & & 7.50 & & \\
\hline & & Nehalpora & 3.70 & & & 7.40 & & \\
\hline & & Sub mean & 3.20 & 2.70 & 3.70 & 7.40 & 7.29 & 7.51 \\
\hline & \multirow{5}{*}{$\begin{array}{l}\text { Baramulla } \\
\text { (Tehsil) }\end{array}$} & Stadium colony & 4.80 & & & 5.70 & & \\
\hline & & Johama & 3.90 & & & 6.00 & & \\
\hline & & Chakla & 5.20 & & & 6.20 & & \\
\hline & & Sub mean & 4.60 & 3.85 & 3.43 & 5.90 & 5.62 & 6.18 \\
\hline & & Mean & 3.39 & 2.12 & 4.66 & 6.50 & 5.62 & 7.38 \\
\hline \multirow[t]{14}{*}{ Budgam } & \multirow[t]{4}{*}{ Khansahib } & Kremshore & 5.10 & & & 5.30 & & \\
\hline & & Khansahib & 3.90 & & & 5.70 & & \\
\hline & & Wager & 3.70 & & & 6.30 & & \\
\hline & & Sub mean & 4.20 & 3.35 & 5.04 & 5.70 & 5.14 & 6.26 \\
\hline & \multirow[t]{4}{*}{ Chadoora } & Bugam & 4.00 & & & 7.40 & & \\
\hline & & Kaisarmulla & 5.01 & & & 7.50 & & \\
\hline & & Nowbugh & 5.00 & & & 7.30 & & \\
\hline & & Sub mean & 4.60 & 3.95 & 5.25 & 7.40 & 7.29 & 7.50 \\
\hline & \multirow[t]{5}{*}{ B.K Pora } & Kuthipora & 3.50 & & & 6.30 & & \\
\hline & & Wagoora & 5.00 & & & 7.51 & & \\
\hline & & Dawlatpore & 4.40 & & & 6.80 & & \\
\hline & & Sub mean & 4.30 & 3.46 & 5.14 & 6.80 & 6.19 & 7.40 \\
\hline & & Mean & 4.36 & 4.13 & 4.39 & 6.60 & 5.63 & 7.54 \\
\hline & \multicolumn{2}{|c|}{ Overall mean } & 3.55 & 2.72 & 4.39 & 6.40 & 6.11 & 6.69 \\
\hline
\end{tabular}


Table.3 Incidence of fruit infection of bottle gourd by Alternaria alternate

\begin{tabular}{|c|c|c|c|c|c|c|c|c|}
\hline \multirow[t]{2}{*}{ District } & \multirow[t]{2}{*}{ Belt } & \multirow[t]{2}{*}{ Locations } & \multirow{2}{*}{$\begin{array}{l}\text { Infected } \\
\text { fruits (\%) }\end{array}$} & \multicolumn{2}{|c|}{ C.I. $(95 \%)$} & \multirow{2}{*}{$\begin{array}{c}\text { Unmarketable } \\
\text { culls }(\%)\end{array}$} & \multicolumn{2}{|c|}{ C.I. $(95 \%)$} \\
\hline & & & & $\begin{array}{c}\text { Lower } \\
\text { Limit }\end{array}$ & $\begin{array}{l}\text { Upper } \\
\text { Limit }\end{array}$ & & $\begin{array}{c}\text { Lower } \\
\text { Limit }\end{array}$ & $\begin{array}{l}\text { Upper } \\
\text { Limit }\end{array}$ \\
\hline \multirow[t]{13}{*}{ Anantnag } & \multirow[t]{4}{*}{ Achabal } & Haji Danter & 5.15 & & & 28.00 & & \\
\hline & & $\begin{array}{l}\text { UttarasooNaji } \\
\text { gund }\end{array}$ & 5.46 & & & 25.00 & & \\
\hline & & Lalan & 5.70 & & & 27.00 & & \\
\hline & & Sub mean & 5.40 & 5.09 & 5.71 & 26.66 & 24.93 & 28.39 \\
\hline & \multirow[t]{4}{*}{ Breng } & Sagam & 6.04 & & & 25.00 & & \\
\hline & & Larnoo & 8.20 & & & 30.00 & & \\
\hline & & HilarArhama & 6.90 & & & 27.00 & & \\
\hline & & Sub mean & 7.04 & 5.81 & 8.27 & 27.33 & 24.48 & 30.18 \\
\hline & \multirow[t]{4}{*}{ Dooru } & Larkipora & 7.50 & & & 26.00 & & \\
\hline & & Shangrin & 5.21 & & & 29.00 & & \\
\hline & & Mehmooabad & 7.36 & & & 23.00 & & \\
\hline & & Sub mean & 6.69 & 5.24 & 8.14 & 26.00 & 23.27 & 30.05 \\
\hline & \multicolumn{2}{|c|}{ Mean } & 6.37 & 5.40 & 7.34 & 26.66 & 25.90 & 27.42 \\
\hline \multirow[t]{13}{*}{ Baramulla } & \multirow[t]{4}{*}{ Sopore } & Arampora & 7.46 & & & 29.00 & & \\
\hline & & Chinkipora & 7.66 & & & 26.00 & & \\
\hline & & Wadura & 6.96 & & & 28.00 & & \\
\hline & & Sub mean & 7.36 & 6.96 & 7.76 & 27.66 & 25.93 & 29.39 \\
\hline & \multirow[t]{4}{*}{ Pattan } & Palhalan & 8.49 & & & 26.00 & & \\
\hline & & Wusan & 5.8 & & & 31.00 & & \\
\hline & & Nehalpora & 6.58 & & & 28.00 & & \\
\hline & & Sub mean & 6.95 & 5.39 & 8.51 & 28.33 & 25.48 & 31.18 \\
\hline & \multirow[t]{4}{*}{$\begin{array}{l}\text { Baramulla } \\
\text { (Tehsil) }\end{array}$} & $\begin{array}{l}\text { Stadium } \\
\text { colony }\end{array}$ & 7.15 & & & 27.00 & & \\
\hline & & Johama & 6.13 & & & 30.00 & & \\
\hline & & Chakla & 6.90 & & & 24.00 & & \\
\hline & & Sub mean & 6.72 & 6.12 & 7.32 & 27.00 & 23.61 & 30.39 \\
\hline & \multicolumn{2}{|c|}{ Mean } & 7.01 & 6.65 & 7.37 & 27.90 & 27.15 & 28.65 \\
\hline \multirow[t]{14}{*}{ Budgam } & \multirow[t]{4}{*}{ Khansahib } & Kremshore & 9.21 & & & 30.00 & & \\
\hline & & Khansahib & 5.40 & & & 27.00 & & \\
\hline & & Wager & 7.54 & & & 29.00 & & \\
\hline & & Sub mean & 7.38 & 5.22 & 9.54 & 28.66 & 26.93 & 30.39 \\
\hline & \multirow[t]{4}{*}{ Chadoora } & Bugam & 7.72 & & & 27.00 & & \\
\hline & & Kaisarmulla & 7.45 & & & 31.00 & & \\
\hline & & Nowbugh & 6.29 & & & 29.00 & & \\
\hline & & Sub mean & 7.15 & 6.29 & 8.01 & 29.00 & 26.74 & 31.26 \\
\hline & \multirow[t]{4}{*}{ B.K Pora } & Kuthipora & 8.59 & & & 28.00 & & \\
\hline & & Wagoora & 8.70 & & & 30.00 & & \\
\hline & & Dawlatpore & 6.46 & & & 25.00 & & \\
\hline & & Sub mean & 7.90 & 6.47 & 9.32 & 27.66 & 24.82 & 30.50 \\
\hline & \multirow{2}{*}{\multicolumn{2}{|c|}{$\begin{array}{l}\text { Mean } \\
\text { Overall mean }\end{array}$}} & 7.48 & 7.05 & 7.91 & 28.44 & 27.66 & 29.22 \\
\hline & & & 6.95 & 6.33 & 7.57 & 27.66 & 26.63 & 28.69 \\
\hline
\end{tabular}


Maximum infected fruits catagorised as unmarketable culls were recorded at Kaisarmulla, Budgam (31\%) followed by Wagoora, Budgam (30\%), Johama, Baramulla (30\%), Shangrin, Anantnag (29\%), Haji-Dantar, Anantnag (28\%), Hilar-Arshama, Anantnag (27\%) and Chinkipora, Baramulla (26\%), respectively. Least percentage of infected fruits was recorded at Haji-Dantar, Anantnag (5.15\%) followed by Uttarasoo-Najigund, Anantnag (5.2\%), Khansahib, Budgam (5.4\%), Lalan, Anantnag (5.7\%), Nowpora, Baramulla (5.8\%), Sangam, Anantnag (6.04\%), Johama, Baramulla (6.13\%) and Nehalpora, Baramulla (6.58\%), respectively. Minimum unmarketable culls were found at Mehmoodabad, Anantnag (23\%) followed by Chakla, Baramulla (24\%), Uttarasoo Najigund Anantnag (25\%), Larkipora, Anantnag (26\%) and Stadium Colony, Baramulla (27\%), respectively.

It is evident from the above that Alternaria leaf spot of bottle gourd is more or less, prevalent in almost every vegetable field growing bottlegourds in Kashmir valley. The disease caused more damage to the foliage which turned senescent in later stages of the disease. Since the literature does not reveal any reference of the disease, pertaining to Jammu and Kashmir, the present investigation seems probably to be the first report of the disease from Jammu and Kashmir. Perusal of the data reveals that out of 3 districts surveyed highest disease incidence $(12.4 \%)$ and intensity (4.36\%) was found in district Budgam in stage first while in stage second highest disease incidence (23.76\%), intensity $(6.6 \%)$, fruit infection $(7.48 \%)$ and unmarketable culls $(28.44 \%)$ was found in district Budgam. Least incidence $(9.25 \%)$ and intensity (2.90\%) was found in district Anantnag in first stage of survey. In second stage of survey least incidence $(22.35 \%)$, intensity $(6.1 \%)$, fruit infection $(6.37 \%)$ and unmarketable culls $(26.66 \%)$ was again found in district Anantnag. So far as the locations are concerned, highest incidence (14.9\%) and intensity $(5.2 \%)$ was recorded in Chakla (Baramulla) during first stage of survey. While minimum incidence $(7.1 \%)$ and intensity
(2.11\%) was recorded in Wadura (Baramulla) during stage first. However, during second stage of survey, highest disease indidence $(26.13 \%)$ was recorded at Lalan (Anantnag), highest intensity $(7.51 \%)$ was recorded at Wagoora (Budgam), highest fruit infection $(9.21 \%)$ at Kremshore (Budgam) and highest unmarketable culls $(31.0 \%)$ was recorded at Kaisarmulla (Budgam).

Minimum disease incidence $(17.46 \%)$ was recorded at HilarArhama (Anantnag), minimum intensity (4.90\%) was recorded at HilarArhama (Anantnag), minimum fruit infection $(5.15 \%)$ at Haji-Dantar (Anantnag) and minimum unmarketable culls (23.0\%) at Mehmoodabad (Anantnag), during the second stage of survey. Bottle gourd cultivation in Chakla, Lalan, Wagoora, Kremshore and Kaisarmulla is carried out under humid condition. Besides this, farmers follow monoculture of cucurbits over large contiguous areas. High levels of disease in these areas may probably be due to humid conditions and monoculture of cucurbits. The disease has been reported to be more severe in presence of abundant atmospheric moisture more than $90 \%$ and high temperature during growing season (Pawar et al., 2014). The data on the infection of bottle gourd fruit reveals that Alternaria leaf spot of bottle gourd is not strictly a foliar disease but affects the fruit also. Out of infected fruits, a good proportion is marketable. Fruits infected severely became mummified or get partially or fully rotten and are as such not accepted in the market. Such fruits were classified as unmarketable culls. Fruit infection due to this disease and fruit rot to the extent that these need to be culled has also been reported by other workers (Singh and Chouhan, 1980).

Alternaria leaf spot (Alternaria alternata) is more or less prevalent in almost every vegetable field of Kashmir valley with varied incidence and intensity from place to place. Highest incidence (14.9\%) and intensity (5.2\%) was recorded in Chakla (Baramulla) during first stage of survey. While minimum incidence $(7.1 \%)$ and intensity $(2.11 \%)$ was recorded in Wadura during stage first. However during second stage of survey highest disease 
incidence $(26.13 \%)$ was recorded at Lalan (Anantnag), highest intensity $(7.51 \%)$ was recorded at Wagoora (Budgam), highest fruit infection (9.21\%) at Kremshore and highest unmarketable culls $(31.0 \%)$ was recorded at Kaisarmulla (Budgam). While minimum disease incidence $(17.46 \%)$ was recorded at HilarArhama (Anantnag), minimum intensity (4.90\%) at HilarArhama (Anantnag), minimum fruit infection $(5.15 \%)$ at Haji-Dantar and minimum unmarketable culls $(23.5 \%)$ at Mehmoodabad, during the second stage of survey. It was observed that Alternaria leaf spot of bottle gourd was not strictly a foliar disease but affected the fruits also resulting in formation of a good proportion of unmarketable culls.

\section{References}

Anonymous, 2016. Package of Practices for Vegetable Crops. Directorate of Extension SKUAST of Jammu, pp.143.

Bhargava, A. K. and Singh, R. D. 1985. Comparative study of Alternaria blight, losses and causal organisms of cucurbits in Rajasthan. Indian Journal of Mycology and Plant Pathology 15: 150-154.

Desai, U. T. and Musmade, A. M. 1998. Pumpkins, Squashes and Gourds. In: Handbook of Vegetable Science and Technology: production, composition, storage and processing (Eds. D. K. Sakunkhe and S. S. Kadam). New York. pp. 273-297.

Maheshwari, S. K., Choudhary, B. R., Sharma, B. D. and Saroj, P. L. 2017. Management of Alternaria leaf blight of Bottle gourd in Western Rajasthan, India. International Journal of Current Microbiology and Applied Sciences6: 1272-1277.

Milind, P. and Kaur, S. 2011. Is bottle gourd a natural guard. International Research Journal of Pharmacy2: 13-17.

Modgil, M., Modgil, R. and Kumar, R. 2004. Carbohydrate and mineral content of chyote (Sechiumedule) and bottle gourd (Lagenaria siceraria). Journal of Human Ecology15: 157-159.

Pawar, R. R., Sapkal, R. T. and Pawar, K. B. 2014. Epidemiology, symptomatology and management of the fruit rot of bottle gourd (Lagenaria siceraria Standl.) caused by Alternaria alternata (Fr.) Keissler. TheBioscan9: 363-370.

Robinson, D. S. 1990. Food Biochemistry and Nutritional Value. Longman Scientific and Technical Publisher, New York. USA. pp. 554.

Seedbold, K. 2010. Foliar Disease of Cucurbits. Plant Pathology Fact Sheet- Cooperative Extention Service. University of Kentucky. pp. 1-4.

Singh, A. K. 1990. Cytogenetics and evaluation in the cucurbitaceae. Cornell University. London. pp. 10-28.

Singh, R. S. and Chouhan, J. S. 1980. Fungal fruit rot of bottle gourd in North India. Indian Phytopathology 33: 598-599

Watt, B. A. 2013. Alternaria leaf blight of cucurbits. Pest Management Fact Sheet\#5086. http://extension.umaine.edu/ ipm/ipddl/publications/5086e.

\section{How to cite this article:}

Masrat Ul Nisar, Nazir Ahmad Bhat, Roaf Ahmad Rather, Farheen Chasti and Tanveer Ahmad Wani. 2018. Status of Alternaria Leaf Spot of Bottle gourd [Lagenaria siceraria (Molina) Standl.] in Temperate Kashmir. Int.J.Curr.Microbiol.App.Sci. 7(10): 2763-2771. doi: https://doi.org/10.20546/ijcmas.2018.710.321 